Review

\title{
Fertility and Pregnancy in End Stage Kidney Failure Patients and after Renal Transplantation: An Update
}

\author{
Maurizio Salvadori ${ }^{1,2, *}$ and Aris Tsalouchos ${ }^{3}$ \\ 1 Department of Renal Transplantation, Careggi University Hospital, viale Pieraccini 18, 50139 Florence, Italy \\ 2 Department of Renal Transplantation, University of Florence, 50139 Florence, Italy \\ 3 Nephrology and Dialysis Unit, Saints Cosmas and Damian Hospital, via Cesare Battisti 2, \\ 51017 Pescia (PT), Italy; aris.tsalouchos@gmail.com \\ * Correspondence: maurizio.salvadori1@gmail.com; Tel./Fax: +39-055-597151
}

check for updates

Citation: Salvadori, M.; Tsalouchos,

A. Fertility and Pregnancy in End

Stage Kidney Failure Patients and

after Renal Transplantation: An

Update. Transplantology 2021, 2 ,

92-108. https://doi.org/10.3390/

transplantology2020010

Academic Editor: Pasquale Esposito

Received: 7 February 2021

Accepted: 30 March 2021

Published: 1 April 2021

Publisher's Note: MDPI stays neutral with regard to jurisdictional claims in published maps and institutional affiliations.

Copyright: (c) 2021 by the authors. Licensee MDPI, Basel, Switzerland. This article is an open access article distributed under the terms and conditions of the Creative Commons Attribution (CC BY) license (https:// creativecommons.org/licenses/by/ $4.0 /)$.

\begin{abstract}
Sexual life and fertility are compromised in end stage kidney disease both in men and in women. Successful renal transplantation may rapidly recover fertility in the vast majority of patients. Pregnancy modifies anatomical and functional aspects in the kidney and represents a risk of sensitization that may cause acute rejection. Independently from the risks for the graft, pregnancy in kidney transplant may cause preeclampsia, gestational diabetes, preterm delivery, and low birth weight. The nephrologist has a fundamental role in correct counseling, in a correct evaluation of the mother conditions, and in establishing a correct time lapse between transplantation and conception. Additionally, careful attention must be given to the antirejection therapy, avoiding drugs that could be dangerous to the newborn. Due to the possibility of medical complications during pregnancy, a correct follow-up should be exerted. Even if pregnancy in transplant is considered a high risk one, several data and studies document that in the majority of patients, the long-term follow-up and outcomes for the graft may be similar to that of non-pregnant women.
\end{abstract}

Keywords: infertility; sexual problems in ESRD; kidney transplantation; pregnancy; teratogenic immunosuppressants; long-term graft outcome

\section{Introduction}

Kidney failure impairs gonadal function. As a consequence, most men and women with end stage kidney disease (ESKD) are infertile [1].

The aim of this review is to clarify the nature of the infertility, how it is possible to become pregnant also in ESKD, and how this condition changes after successful kidney transplantation.

In addition, the new problems that arise in pregnancy after kidney transplantation will be examined and discussed.

\section{Fertility Disorders in Men with ESKD}

A high number of men with advanced chronic kidney disease (CKD) have disturbances both in sexual and reproductive function.

Erectile dysfunction is a common manifestation of sexual dysfunction and the disorder is reported in approximately $80 \%$ of patients in hemodialytic treatment (HD) [2-4]. The dysfunction is associated to disturbances in the vascular system, neurologic system, and endocrine system [5-7] (Table 1). 
Table 1. Factors involved in the pathogenesis of erectile dysfunction in uremic men.

\begin{tabular}{ll}
\hline \multicolumn{2}{l}{ Vascular System } \\
\hline$-\quad$ Occlusive arterial disease \\
$-\quad$ Veno-occlusive disease and venous leakage \\
\hline Neurologic system \\
\hline$-\quad$ Impaired autonomic function due to uremia \\
- $\quad$ Co-morbid conditions \\
\hline Endocrine system \\
\hline - $\quad$ Reduced gonadal function \\
- $\quad$ Reduced hypothalamic-pituitary function \\
\hline Psychologic system \\
\hline Other factors \\
\hline - $\quad$ Zinc deficiency \\
- $\quad$ Medications \\
- $\quad$ Snemia \\
\hline
\end{tabular}

In addition, decreased libido and a decline in the frequency of intercourse are generally associated to erectile dysfunction.

ESKD causes hormonal changes, even if the exact pathogenetic mechanisms are still poorly understood. Testosterone is reduced in ESKD [8] and its levels are inversely related to inflammation markers [9]. On the contrary, men affected by ESKD have high levels of luteinizing hormone (LH) and of follicle stimulating hormone (FSH) [1]. This is principally due to the alterations of the hypothalamic-pituitary gonadotropin axis that affects both men and women with ESKD [10] (Figure 1).

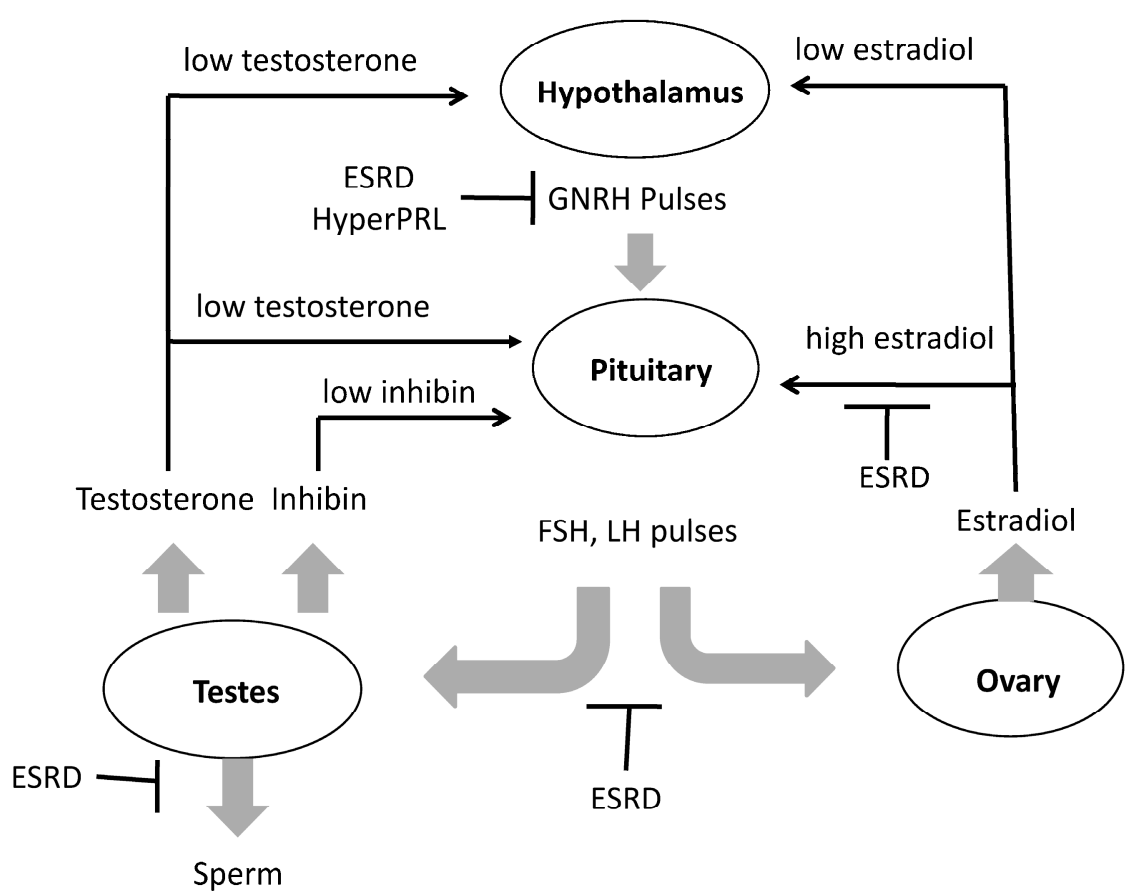

Figure 1. The hypothalamic-pituitary-gonadotropin axis in men and women with ESRD. ESRD = end stage renal disease. $\mathrm{PRL}=$ Prolactin. $\mathrm{GNRH}=$ Gonadotropin releasing hormone. $\mathrm{FSH}=$ Follicle stimulating hormone. $\mathrm{LH}=$ Luteinizing hormone. 
In particular, LH is high in the blood of uremic men [11]. This could be due to the reduced levels of testosterone because there is a feedback between testosterone and inhibition of LH. In addition, there is an alteration in the release of gonadotropin-releasing hormone $(\mathrm{GnRH})$ that is also responsible for a hypogonadal state and that is caused by inadequate nutrient intake, stress, and systemic illness [12]. FSH secretion is also increased in men affected by CKD. High FSH levels represent a poor prognosis for a recovery of spermatogenic function [13]. In addition, prolactin (PRL) levels are high in ESKD. This fact, according to several studies, may be ascribed to secondary hyperparathyroidism [14].

ESKD causes an impaired spermatogenesis. The analysis of semen documents an oligoasthenozoospermia [15] and an atrophy of Sertoli cells [10]. Other studies [16] documented a reduced sperm viability and motility in ESKD patients compared to controls. Different new studies [17] document a relationship between the reduced fertility and the expression of the gene for cystic fibrosis (CFTR).

The effects of CKD/ESKD on hypothalamic-pituitary and testicular function are shown in Table 2.

Table 2. Effects of chronic kidney disease (CKD)/end stage kidney disease (ESKD) on hypothalamicpituitary-testicular functions.

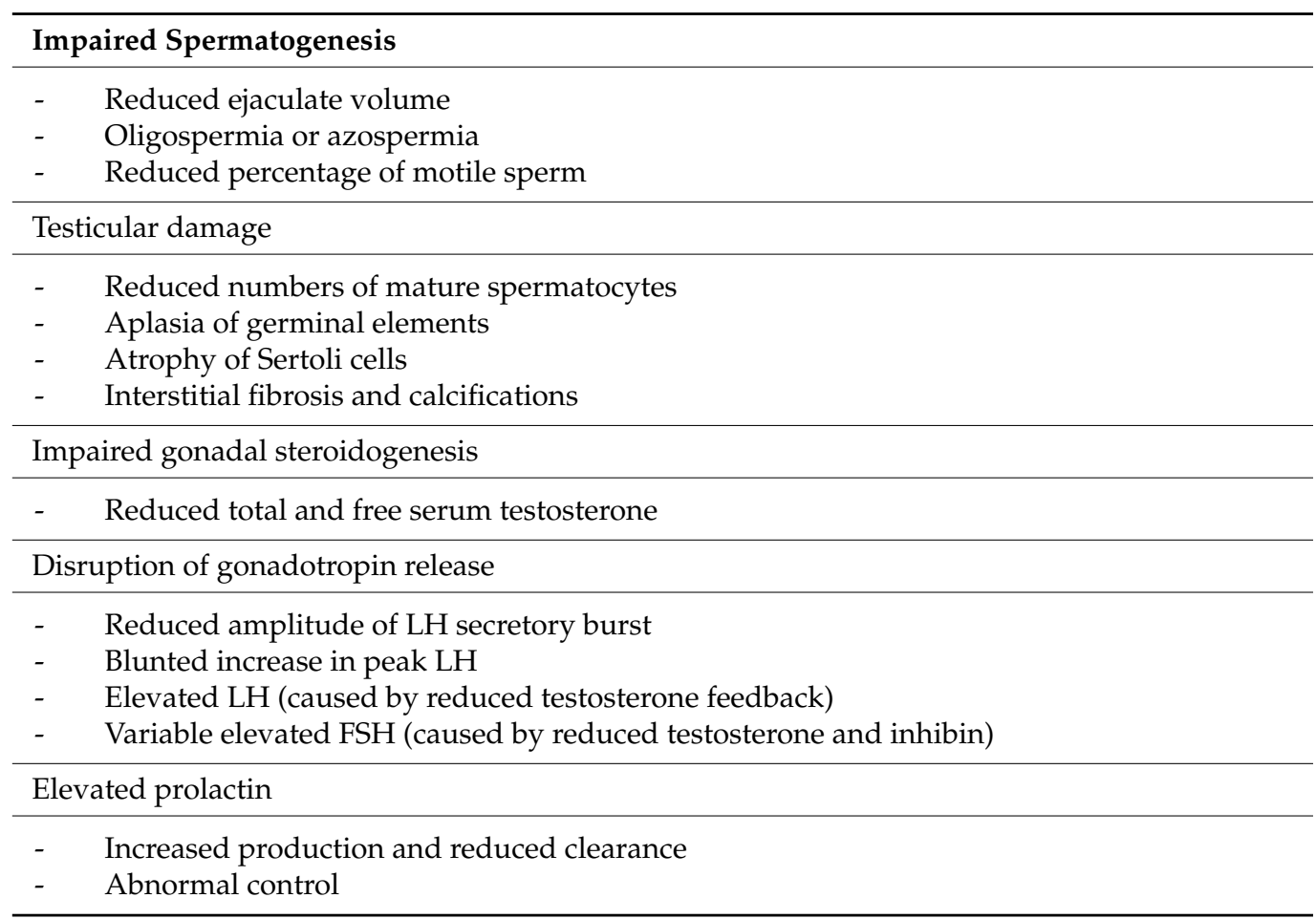

The treatment of sexual dysfunction in uremic men consists principally in optimizing the dialysis treatment and in providing an optimal nutrition.

In addition, the administration of erythropoietin reduces $\mathrm{LH}$ and FSH and increases testosterone $[18,19]$.

A specific treatment is Sildenafil, a phoshodiesterases inhibitor, that was proven to be principally useful for patients with psychogenic, vascular, or neurogenic causes of erectile dysfunction [20].

The best solution is obviously kidney transplantation.

\section{Fertility Disorders in Women with ESKD}

A decreased reproductive function and consequent infertility is common in women with ESKD [21-23]. The prevalence of infertility in several studies is as high as $92 \%$. 
Using data from different registries, it was shown that in Italy, the pregnancy rate in the population on hemodialysis (HD) is $0.7-1.1$ per 1000 women [24]. Similar data are reported for the UK $[25,26]$. Different factors are responsible for the reduced fertility (Table 3).

Table 3. Factors responsible for the reduced fertility in women with ESKD.

\begin{tabular}{l}
\hline Abnormal levels of sex hormones \\
\hline Menstrual disorders \\
\hline Abnormal endometrial morphology \\
\hline Reduced ovarian reserve \\
\hline Reduced libido and sexual dysfunction \\
\hline
\end{tabular}

\subsection{Female Sex Hormones}

The aforementioned alterations of the hypothalamus-pituitary hormone axis (Figure 1) affect both women and men. In women, this alteration is characterized by an increase of LH and FSH and with reduced estrogen levels. In ESKD, there is a loss of the normal pulsatile release of GnRH from the hypothalamus with loss of the cycle LH-FSH [27]. The reduced estrogen levels do not provide the positive feedback to the hypothalamus. The overall result is the anovulation. In addition, women with ESKD have a high PRL level that contributes to the disturbance.

\subsection{Menstrual Disorders}

Menstrual disorders are common in patients with ESKD. A survey conducted on 75 women with ESKD on HD documented that 75\% of them had menstrual disorders [28]. The vast majority of women with ESKD have a functional menopause [29], and menstrual disorders as amenorrhea, polymenorrhea, and oligomenorrhea are common. This functional menopause may be reversed by optimizing the HD treatment and, most of all, with kidney transplantation [30-32].

\subsection{Endometrial Morphology}

Endometrial biopsies of women on HD documented that the reduced level of estrogens is associated with endometrial atrophy.

Overall, one third of women has a reduction in proliferation and half of women has endometrial atrophia or subatrophia [28].

\subsection{Ovarian Reserve}

Overall, women with ESKD have reduced levels of anti-Mullerian hormone (AMH) which is a marker of ovarian reserve. A recent study aimed to investigate AMH levels in 77 women with ESKD or transplanted kidneys. AMH levels were lower in patients with ESKD or transplanted kidneys, but higher in patients on HD [33]. The finding of higher $\mathrm{AMH}$ in patients on HD remains unclear.

\subsection{Reduced Libido and Sexual Dysfunction}

The prevalence of sexual dysfunction in women with ESKD is high and caused by different factors as loss of libido, failure of vaginal lubrification, and orgasmic impairment [34]. A review on sexual dysfunction in ESKD women identified a significant sexual dysfunction in 306 subjects [4].

\section{Pregnancies and Deliveries in ESKD Women}

A recent study carried out in the USA [35] on obstetric deliveries in women with ESKD in the period 2002-2015 documented the following data.

The delivery rate in women with ESKD increased from 2.6 to 3.8 per 1000 patients/year and the delivery rate in women on HD increased from 2.1 to 3.6 per 1000 patients/year. 
Preterm delivery was observed in $41 \%$ of patients.

The ANZDATA registry reported a preterm delivery rate of $46.6 \%$. A higher incidence was reported by an Italian registry, with a preterm delivery rate as high as 90.5\% [36,37].

Pregnancy rates in women on peritoneal dialysis (PD) are lower than on HD. In the survey on pregnancy and ESKD from the United States, $1.1 \%$ of reproductive-age women on PD conceived versus $2.4 \%$ on HD [35]. Data from the ANZDATA Registry also reported lower conception rates in women on PD compared to HD (1.06 vs. 2.54 pregnancies per 1000 patient/year) [36].

\section{Strategies to Improve Fertility in Women with CKD}

Three major strategies warrant mention:

- Avoidance of dangerous and ovarian-toxic drugs

- Improvement of dialysis strategy

- Kidney transplantation

\section{Avoidance of Dangerous Drugs}

Cyclophosphamide, an alkilating agent, is principally used in the treatment of lupus nephritis and membranous glomerulonephritis. The drug has a gonadotoxic profile and reduces the ovarian reserve [38]. In addition to reducing the cyclophosphamide dosing, it is possible to protect the ovarian reserve with an LH-releasing hormone [39]. A large trial with LH-releasing hormone in the breast cancer population confirms the efficacy of this strategy [40].

Cyclophospamide that has been used in the past to treat glomerulonephritis could have an impact on fertility, eventually adding to other factors in ESKD patients.

Patients affected by ESKD and who did receive cyclophosphamide should be advised of the risk before pregnancy.

\section{Intensive HD}

Several data suggest that intense HD increases pregnancy rates in women with ESKD [41]. Additionally, intensive HD has been documented to be able to restore eumenorrhea in women with ESKD [42].

Overall, even if reported data on pregnancy on dialysis are heterogeneous, the HD schedule is the main determinant of pregnancy rates and outcomes [43].

Several authors were investigating whether there was an association of hours of HD and biochemical parameters.

After a Kidney Disease Outcome Quality Index (KDOQI) recommendation of long and frequent $\mathrm{HD}$ in the setting of pregnancy, in 2019 the clinical practice guidelines from the UK recommended a midweek predialysis blood urea nitrogen (BUN) of $<35 \mathrm{mg} / \mathrm{dL}$ [44].

The effect of dialysis membrane is unknown, even if hemodiafiltration has been shown to be associated with a $100 \%$ live birth rate.

\section{Kidney Transplantation}

Kidney transplantation, when possible, is the best solution to partially or completely restore fertility both in women and in men.

\subsection{Sexual and Reproductive Health after Kidney Transplantation}

After successful kidney transplantation women, recover the functions of the hypothalamuspituitary-ovarian axis [45] and experience menses and ovulation [46]. Post-transplantation, women have a significant reduction in LH, FSH, and prolactin (PRL) with an increase of estrogen. As a consequence, transplanted women have a tenfold increase in pregnancy rate compared to women on HD.

After transplantation, men also experience an improved hypothalamus-pituitarytesticular function. In a study on 30 subjects [47] after transplantation, a normalization of LH and PRL was observed. The testosterone levels increased even if the levels remained 
lower than those of healthy subjects [48]. A different and more recent study [49] reported normal testosterone levels. Age, previous renal disease, co-morbidities, and type of immunosuppression may explain such different data. Differently from the normalization of hormone levels, poor results are reported on the quality of semen and spermatogenesis $[47,48]$. The aforementioned study [46] documented an improvement in sperm count, but only a small improvement in motility and morphology. Previous studies [50,51] performing testicular biopsies before and after transplantation documented an increase in the number of spermatocytes without change in the Sertoli cells. In addition, the improvement of spermatogenesis was observed only in a small number of patients suggesting that the morphologic alterations and fibrosis observed in uremia do not improve after transplantation. A different study [52] observed two groups of patients after transplantation. The so-called "fertile group" had normal sperm concentration, while the "infertile group" had oligospermia and a reduced motility. The authors ascribed these differences to different cyclosporine levels, but other factors may be involved as well.

After transplantation the disturbances in sexual problems do not seem to disappear in all patients. Indeed, in a Dutch study [53], the persistence of sexual problems even after transplantation was analyzed and compared to the general population. After kidney transplantation $48.3 \%$ of men and $44.4 \%$ of women were affected by sexual problems also independently from the normalization of the pathophysiological abnormalities that characterize patients affected by ESKD. Only in male patients, there was an association between the prevalence of sexual problems and age.

Reduction in libido, erectile dysfunction, and orgasm complaints were the most common disturbances in transplanted men, while reduction in libido, reduced vaginal lubrification, and orgasm complaints were the most common disturbances in transplanted women.

There are strategies to improve fertility in ESKD in men and women, independently from kidney transplantation.

Some strategies are effective in both gender, others are more effective in one gender with respect to the other.

Intensive HD is effective both in women and in men [41,42]. An Australian study [42] documented that a more intensive HD in men was able to increase testosterone levels and to decease PRL.

Similarly, an optimal nutritional status and the administration of erythropoietin have beneficial effects on fertility in both genders $[18,19]$.

The benefit of hormone replacement therapy (HRT) in women may be useful. Data from the US Renal Data System revealed that HRT use in women with ESKD was more common in younger women, with high education levels and belonging to the white race [54].

In men with ESKD, several studies have shown that improved testosterone levels were associated with improved sexual satisfaction [55]. Other studies did not confirm these results.

In conclusion, both for men and women with ESKD, the mainstays of treatment for sexual dysfunction are optimizing HD, avoiding medications that interfere with sexual desire correcting mineral abnormalities and anemia, and addressing psychological issues.

\subsection{Pregnancies after Kidney Transplantation}

Independently from some residual sexual dysfunction after successful kidney transplantation, the increasing rates of pregnancies after transplantation are the most important signal of the recovering of an almost healthy condition after the uremic condition.

The first pregnancy in a transplanted woman with a healthy baby was described in 1958 [56]. Many years later, Johns Hopkins group reported a meta-analysis including 4706 pregnancies in 3570 kidney recipients [57]. In this meta-analysis, an association between maternal age and pregnancy outcomes was found. Younger mean maternal age was associated with greater live birth outcomes and lower incidence of miscarriage and still-birth. A different analysis was reported by a longitudinal study of 30,078 transplant re- 
cipients [58]. In this analysis, the pregnancy rate was 33 per 1000 compared with more than 100 per 1000 in the general population. The Transplant Pregnancy Registry International (TPR) reported in 2018 a total of 1993 pregnancies in 1101 kidney transplant recipients in the USA [59].

However, pregnancy after kidney transplantation should be considered at high risk with increased risks for the fetus and the mother [60]. Indeed, live birth rates are approximately 80\% [61]. Similarly, high rates of Caesarean sections and preterm deliveries, and an increased rate of low birth weight are reported [61].

Several factors justify this increased risk and should be carefully examined.

\subsection{Renal Modifications during Pregnancy}

During pregnancy, under normal conditions, there is an increase of renal blood flow with an increase of renal dimensions; a physiological hydronephrosis due to hormones and compression. These two physiological modifications are extremely important in pregnancies after kidney transplantation: the first one may cause a glomerular hypertension responsible for glomerulosclerosis; the second one may facilitate renal infections. In addition, during pregnancy, there is an increase of glomerular filtration rate (GFR), a reduction of serum levels of creatinine, uric acid, the appearance of mild hematuria and mild proteinuria, and an increase of aldosterone and prostaglandins [62].

\subsection{Maternal Complications}

Most relevant maternal complications reported in pregnancies after kidney transplantation are hypertension, preeclampsia, and diabetes [63]. Other maternal complications are represented by an increased rate of infections [64] and acute rejection, more frequent in sensitized patients $[65,66]$.

Hypertension during pregnancy accounts for approximately $54 \%$ of patients and is probably related to the side effects of immunosuppressive agents. Hypertension is more common in kidney transplant patients vs. liver transplant patients. This fact is probably due to the long standing pre-transplant hypertension [67]. Preeclampsia has been observed in $27 \%$ of patients.

Gestational diabetes has been observed in $8 \%$ of patients and again immunosuppressive agents may play a role in favoring diabetes. Gestational diabetes is more common in kidney transplants compared to liver transplants and controls ( $8 \%$ vs. $5 \%$ vs. <4\%) [68].

Infections are other common complications in post-transplant pregnancies. The incidence is from $20 \%$ to $40 \%$ [69]. Vesicoureteral reflux is common also in asymptomatic recipients and ureteric dilation and immunosuppressive agents may favor urinary tract infections.

Anemia is also a frequent complication. Physiologic hemodilution and again immunosuppressive agents may be responsible [70].

It is still debated whether pregnancy increases the risk of graft rejection.

A review of different registries documents an increased risk of graft rejection only in sensitized patients $[65,66]$. The National Transplantation Pregnancy Registry (NTPR) recommends performing a kidney biopsy in all cases of graft dysfunction in pregnancy. The prevalence of rejection during pregnancy in the NTPR is reported at $0.9 \%$ for kidney transplantation, with a prevalence of $1.4 \%$ in the first three months post-partum [71]. Data from the UK documented lower rejection episodes in women who became pregnant more than 12 months after transplantation [71,72]. Similar data have been recently reported by US Medicare [30].

\subsection{Counseling}

Such a high rate of complications highlights the opportunity of pre-pregnancy counseling and a close follow-up during the pregnancy. Unfortunately, according to the data of Yildizim et al., only 50\% of pregnant women have received appropriate counseling [73].

In a study by Rafie et al. [74] conducted in the USA, women with renal transplants and of reproductive age principally used condoms to avoid pregnancy but were wondering 
about alternative methods. In a study from Xu et al. [75], 56\% of women transplanted in China did not use any birth control method because they had not been informed about the potential of controlling a high risk pregnancy.

The relevance of complete counseling is highlighted by several studies [76].

According to the Kidney Disease Improving Global Outcomes (KDIGO) recommendations, in the counseling sessions the following points should be clarified [77]:

- Discussion on sexual activity and counseling about contraception;

- Recommend at least 1 year after transplantation before becoming pregnant;

- Discuss the different immunosuppressive therapies and highlight which ones should be discontinued and replaced;

- Counseling pregnant transplanted women on the risks and benefits of breastfeeding; and

- $\quad$ Refer pregnant women to an obstetrician with expertise in managing high-risk pregnancies.

\subsection{Timing of Conception, Mother Medical Condition before pregnancy, Follow-Up Recommended} during Pregnancy

The American Society of Transplantation recommends avoiding pregnancy in the first year after transplantation. The already-mentioned study by Gill et al. [58] and a more recent study by Rose et al. [30] reported an increased risk of miscarriage or of graft failure for pregnancies in the first year post-transplantation.

In addition, the mother should be less than 30-35 years old, non-obese, and nondiabetic [78,79]. Renal function should be good (above $60 \mathrm{~mL} / \mathrm{min}$ ) and stable with proteinuria below $300-500 \mathrm{mg} /$ day, without rejection in the last year, absence of hypertension, or with a good control. Additionally, absence of recurrent urinary tract infection, normal ultrasound of the graft, and discontinuations of potentially teratogenic drugs are requested [80-82].

Follow-up should be intensified in kidney transplant pregnancies relative to normal pregnancies because kidney transplant pregnancies should be considered at high risk, including in recipients that meet a perfect profile at transplantation.

The suggested follow-up includes a nephrology consult with blood and urinary tests every $2-4$ weeks. In addition to blood and urinary tests, a graft ultrasound is recommended principally when it has not been performed before. A urinary culture is also recommended because kidney transplant pregnant women are at risk for urinary tract infections. It is also recommended to carefully monitor the immunosuppressive drug levels at least two times monthly. A dosage adjustment may sometimes be necessary [83].

\subsection{Immunosuppressive Agents}

This is one of the most relevant issues for pregnancies after kidney transplantation because of their possible teratogenic effect.

Since 2006, the Food and Drug Administration (FDA) classified the immunosuppressive agents according their possible teratogenic effect [84]. Later, the FDA revised the classification on 2015 and Table 4 shows the new classification. According to the FDA classification, category A includes drugs which failed to demonstrate risks in well conducted studies; category B includes drugs that failed to document risks in animal studies, but the drugs have not been tested in controlled studies in pregnant women; category $\mathrm{C}$ includes drugs that have shown adverse effects in animal studies, but no controlled studies have been conducted in women for ethical problems because their use is essential after transplantation; category D includes drugs with documented risks in human fetal studies, but again, at least some of these drugs are acceptable because of their essential effect in transplant patients. 
Table 4. Immunosuppressive drugs used in transplantation.

\begin{tabular}{|c|c|c|c|}
\hline Drug & Usual Dosage Range & Animal Reproductive Data & $\begin{array}{c}\text { FDA Pregnancy } \\
\text { Category }\end{array}$ \\
\hline $\begin{array}{c}\text { Corticosteroids } \\
\text { Prednisone } \\
\text { Methylprednisolone }\end{array}$ & $\begin{array}{c}\text { 5-20 mg/day } \\
500-1000 \mathrm{mg} / \text { day } \\
\text { (antirejection) }\end{array}$ & $\begin{array}{l}\text { Yes } \\
\text { Yes }\end{array}$ & $\mathrm{C}$ \\
\hline Azathioprine & $0.5-1.0 \mathrm{mg} / \mathrm{kg} /$ day & Yes & $\mathrm{D}$ \\
\hline Cyclosporine & $2-10 \mathrm{mg} / \mathrm{kg} /$ day & Yes & $\mathrm{C}$ \\
\hline Tacrolimus & $0.05-0.2 \mathrm{mg} / \mathrm{kg} /$ day & Yes & $\mathrm{C}$ \\
\hline Mycophenolate mofetil & 1000-2000 mg/day & Yes & $\mathrm{D}$ \\
\hline Mycophenolic acid & 720-1440 mg BID & Yes & $\mathrm{D}$ \\
\hline Sirolimus & 2-5 mg/day & Yes & $\mathrm{C}$ \\
\hline Everolimus & $5-10 \mathrm{mg} / \mathrm{kg}$ & Yes & $\mathrm{C}$ \\
\hline
\end{tabular}

\section{Corticosteroids}

Corticosteroids pass across the placenta, where $90 \%$ are metabolized into inactive forms [85]. Corticosteroids may have adverse effects on glucose metabolism, thus favoring gestational diabetes.

Animal studies report an increased risk of cleft palate, but this has not been confirmed in humans [86].

Together with azathioprine (AZA), they are the most employed and best known drugs.

\section{Calcineurine Inhibitors (CNI)}

Calcineurine inhibitors (CNI) include tacrolimus (TAC) and Cyclosporine A (CsA). Both drugs pass across the placenta, but the degree of transfer is limited [87]. In the mother, they may favor hypertension as in all transplanted subjects.

Animal studies showed skeletal retardation with CsA exposure, not confirmed in humans [88]. Overall, both drugs are considered safe [89].

\section{Azathioprine (AZA)}

Maternal and fetal exposure appears to be similar, but the fetus does not convert AZA to the active and possibly teratogenic 6-mercaptopurine.

Animal studies reporting congenital malformations have not been confirmed in humans. KDIGO and European Best Practice Guidelines suggest switching from mycophenolate to azathioprine before pregnancy [90].

\section{Mycophenolic Acid (MPA)}

Mycophenolic acid (MPA) crosses the placenta and exerts adverse fetal effects. A multinational European prospective study reported a risk of miscarriage. Furthermore, there was a prevalence of preterm birth and low birth weight [91]. Congenital malformations due to MPA have been reported in several studies [92,93]. Corpus callosus agenesis, myelomeningocele, atrial septum defect, and trachea-esophageal atresia are among the most relevant malformations. MPA should be interrupted and replaced before conception.

In a study from the TPR, the negative effect of MPA on live births and miscarriages is well documented in pregnant women with MPA exposure during pregnancy with respect to women who discontinued MPA pre-conception [94].

In the study, 96 pregnant recipients who were on MPA during pregnancy were compared with 188 pregnant recipients who discontinued MPA pre-conception. The pregnancies who discontinued MPA had a significantly higher rate of live births and a lower incidence of birth defects. Acute rejection rates during pregnancy and postpartum were slightly higher in the MPA exposed group. 


\subsection{Sirolimus and Everolimus}

In females with kidney transplantation, an increased prevalence of hypogonadism, dysmenorrhea, ovarian cysts, and infertility has been documented [95].

Very few studies have considered the use of mammalian target of rapamycin (mTOR) inhibitors (mTORIs) in pregnancy. These drugs are teratogenic in animals and KDIGO guidelines suggest discontinuation before pregnancy. In humans, few case reports highlight successful pregnancies [96].

\subsection{Rituximab, Simulect, Belatacept}

Too few studies have been made to allow their safe use in pregnancy [34,97]. There is a need to obtain further evidence.

\section{Pregnancies with Father Transplanted and Immunosuppressed}

This topic is not frequently treated but is extremely important.

Data on paternal exposure to corticosteroids, CNIs, and AZA do not document an increased risk of obstetric complications or congenital malformations [98].

MPA is teratogenic. The TPR reported data on 152 male transplant patients on MPA. The rate of obstetric complications or malformations was similar to that of the general population [99]. These data were confirmed by a Norway study on 350 pregnancies. The study did not observe differences between pregnancies from fathers on MPA or not [100].

The use of mTORIs in males has severe effects on fertility. Less mobile spermatozoa, lower sperm count, and lower pregnancy rate has been observed in males on mTORIs [101-103]. An anti-HPG effect has also been described [101]. Patients should be counseled on the risk of mTORIs for male fertility [104].

Based on the aforementioned studies, a double or triple maintenance immunosuppression with corticosteroid, MPA, and CNI is given to male kidney transplant patients seeking paternity.

Clinicians should be advised of the risk in using mTORIs.

\section{Deliveries in Kidney Transplant Women}

As repeatedly mentioned above, pregnancy in kidney transplant recipients should always be considered at high risk both for the mother and the fetus [105] (Figure 2).

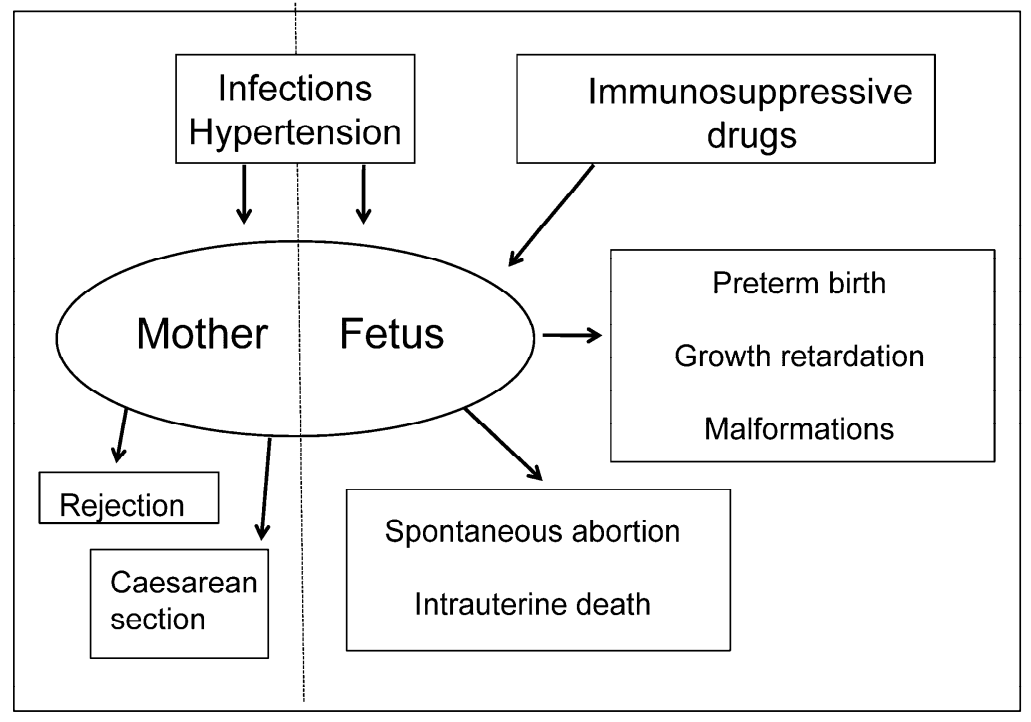

Figure 2. Risks of pregnancy in transplant recipients for mother and child.

Several monocenter and national registries have highlighted the higher rate of delivery complications. Piccoli et al. [106] compared 189 kidney transplant pregnancies with 1418 
low risk pregnancies in Italy. The study found a significant higher risk for Caesarean sections, preterm deliveries, and lower weight at birth (smaller for gestational age) in kidney transplant deliveries [107]. All parameters were highly significant $(p<0.001)$. The same authors did not find significant differences in the different study periods. In a different study, Gill et al. [58] found a reduction of delivery problems according to the post-transplant years of conception with lower problems for conceptions more distant from renal transplantation. A UK National Cohort Study compared 105 kidney transplant deliveries in the period from 2007 to 2009 with the national data of the same period [76]. Kidney transplant deliveries had a higher and significant odd ratio for premature births $(\mathrm{OR}=12.57)$, small weight for gestational age $(\mathrm{OR}=2.92)$, and congenital anomalies $(\mathrm{OR}=2.46)$. A recent meta-analysis and systemic review analyzed 6712 pregnancies in 4174 kidney transplant recipients [108]. In this analysis, miscarriages were $15.4 \%$, Caesarean sections $62.6 \%$, and preterm deliveries $43.1 \%$. The authors concluded that, even if the outcomes of live births are overall favorable, the risks of delivery complications are high and patient counseling and clinical decision making should always be considered.

However, it should be considered that favorable outcomes have also been reported for other organs. In an analysis in 2015 [109], data were reported from the already-cited NTPR. In the study, 1581 pregnancies in kidney transplant patients, 376 in liver transplant patients, 102 in kidney-transplant patients, 122 in heart transplant patients, 33 in lung transplant patients, and 20 in heart-lung transplant patients were reported. Overall, the maternal complications and the obstetric outcomes were similar for any transplant considered.

\section{Long-Term Outcomes for the Graft}

Overall, renal allograft outcomes in pregnant transplant recipients with a well-functioning graft appear to be comparable with that of non-pregnant transplant recipients [110-112].

However, two points in particular warrant analysis: the long-term graft function after pregnancy in kidney transplant recipients and the risk factors for graft loss.

A small but significant rise in serum creatinine within 2 years after delivery has been observed in three studies [113-115]. This fact could be ascribed to physiological modifications after pregnancy. According one of these studies [114], the higher serum creatinine could also be due to a higher prevalence of risk factors in the study population as hypertension or higher serum creatinine before pregnancy.

Most importantly, in a recent, systematic review [60], no increase in serum creatinine was observed at 5 years after delivery. This observation has been confirmed by three studies: the ANZDATA analysis [116], the Rahamimov et al. study on 39 patients with a 15 years follow-up [117], and the TPR annual report with data from 1031 patients from 1097 to 2016 [59].

Risk factors for graft loss after pregnancy are hypertension before or during pregnancy, proteinuria before pregnancy, transplant to conception interval (TCI), and preconception graft function as observed in the European and American guidelines [82,90] (Table 5). This last factor seems to have a particular importance. The aforementioned study of Rose et al. [30] observed 729 pregnancies in kidney transplant recipients between 1990 and 2010 and found that pregnancies in the first or second, but not the third post-transplant year was associated with an increased risk of death-censored graft loss.

Table 5. Risks factors for graft loss after pregnancy.

\begin{tabular}{l}
\hline Hypertension before or during pregnancy \\
\hline Proteinuria before pregnancy \\
\hline Transplant to conception interval \\
\hline Pre-conception graft function \\
\hline
\end{tabular}




\section{Conclusions}

Sexual problems and infertility are a major problem in patients affected by ESKD that represent a severe limitation to their life. The problem affects both men and women. Few medications are able to improve this condition reversing to a normal sexual life. Probably the most effective treatment is a well-conducted HD. Thanks to a well-conducted HD, other medication, and psychological assistance, several pregnancies have been successfully experienced by women on HD treatment.

Clearly, kidney transplantation represents the best solution to recover an almost normal sexual life with successful pregnancies.

However, pregnancy in renal transplant patients is considered high-risk and several precautions should be undertaken to avoid risks.

Time of conception after transplant, healthy conditions at the time of conception, avoiding dangerous immunosuppressants, and a careful follow up by nephrologist and obstetrician are among the most important issues. Correct counseling is the basis for a well-conducted pregnancy.

Author Contributions: M.S. and A.T. contributed equally to the manuscript; M.S. designed the study, performed the last revision, and provided answers to the reviewers. A.T. collected the data from literature. M.S. and A.T. analyzed the collected data and wrote the manuscript. Both authors have read and agreed to the published version of the manuscript.

Funding: This research received no external funding

Institutional Review Board Statement: Ethical review and approval were waived for this study, due to the fact that this is a review of studies conducted by others and does not contain any personal study.

Informed Consent Statement: Ethical review and approval were waived for this study, due to the fact that this is a review of studies conducted by others and does not contain any personal study.

Data Availability Statement: All data and studies may be found in Pub Med Central.

Conflicts of Interest: Maurizio Salvadori and Aris Tsalouchos do not have any conflict of interest in relation to the manuscript.

\section{References}

1. Holley, J.L.; Schmidt, R.J. Changes in Fertility and Hormone Replacement Therapy in Kidney Disease. Adv. Chronic Kidney Dis. 2013, 20, 240-245. [CrossRef] [PubMed]

2. Rosas, S.E.; Joffe, M.; Franklin, E.; Strom, B.L.; Kotzker, W.; Brensinger, C.; Grossman, E.; Glasser, D.; Feldman, H. Prevalence and de-terminants of erectile dysfunction in hemodialysis patients. Kidney Int. 2001, 59, 2259-2266. [CrossRef] [PubMed]

3. Türk, S.; Karalezli, G.; Tonbul, H.Z.; Yıldız, M.; Altıntepe, L.; Yıldız, A.; Yeksan, M. Erectile dysfunction and the effects of sildenafil treatment in patients on haemodialysis and continuous ambulatory peritoneal dialysis. Nephrol. Dial. Transplant. 2001, 16, 1818-1822. [CrossRef]

4. Navaneethan, S.D.; Vecchio, M.; Johnson, D.W.; Saglimbene, V.; Graziano, G.; Pellegrini, F.; Lucisano, G.; Craig, J.C.; Ruospo, M.; Gentile, G.; et al. Prevalence and Correlates of Self-Reported Sexual Dysfunction in CKD: A Meta-analysis of Observational Studies. Am. J. Kidney Dis. 2010, 56, 670-685. [CrossRef]

5. Billups, K.L. Erectile dysfunction as a marker for vascular disease. Curr. Urol. Rep. 2005, 6, 439-444. [CrossRef] [PubMed]

6. Campese, V.M.; Procci, W.R.; Levitan, D.; Romoff, M.S.; A Goldstein, D.; Massry, S.G. Autonomic nervous system dysfunction and impotence in uremia. Am. J. Nephrol. 1982, 2, 213-220. [CrossRef]

7. Holdsworth, S.R.; de Kretser, D.M.; Atkins, R.C. A comparison of hemodialysis and transplantation in reversing the uremic dis-turbance of male reproductive function. Clin. Nephrol. 1978, 10, 146-150.

8. Reinhardt, W.; Kübber, H.; Dolff, S.; Benson, S.; Führer, D.; Tan, S. Rapid recovery of hypogonadism in male patients with end stage renal disease after renal transplantation. Endocrine 2018, 60, 159-166. [CrossRef]

9. Carrero, J.J.; Qureshi, A.R.; Nakashima, A.; Arver, S.; Parini, P.; Lindholm, B.; Bárány, P.; Heimbürger, O.; Stenvinkel, P. Prevalence and clinical implications of testosterone deficiency in men with end-stage renal disease. Nephrol. Dial. Transplant. 2011, 26, 184-190. [CrossRef]

10. Holley, J.L. The hypothalamic-pituitary axis in men and women with chronic kidney disease. Adv. Chronic Kidney Dis. 2004, 11, 337-341. [CrossRef]

11. Lim, V.S.; Fang, V.S. Restoration of plasma testosterone levels in uremic men with clomiphene citrate. J. Clin. Endocrinol. Metab. 1976, 43, 1370-1377. [CrossRef] [PubMed] 
12. Ayub, W.; Fletcher, S. End-stage renal disease and erectile dysfunction. Is there any hope? Nephrol. Dial. Transplant. 2000, 15, 1525-1528. [CrossRef] [PubMed]

13. Phocas, I.; Sarandakou, A.; Rizos, D.; Kapetanaki, A. Serum alpha-immunoreactive inhibin in males with renal failure, under haemodialysis and after successful renal transplantation. Andrologia 1995, 27, 253-258. [CrossRef] [PubMed]

14. Isaac, R.; Merceron, R.E.; Caillens, G.; Raymond, J.-P.; Ardaillou, R. Effect of Parathyroid Hormone on Plasma Prolactin in Man. J. Clin. Endocrinol. Metab. 1978, 47, 18-23. [CrossRef]

15. Lessan-Pezeshki, M.; Ghazizadeh, S. Sexual and reproductive function in end-stage renal disease and effect of kidney transplantation. Asian J. Androl. 2008, 10, 441-446. [CrossRef]

16. Xu, L.-G.; Xu, H.-M.; Zhu, X.-F.; Jin, L.-M.; Xu, B.; Wu, Y.; Lu, N.-Q. Examination of the semen quality of patients with uraemia and renal transplant recipients in comparison with a control group. Andrologia 2009, 41, 235-240. [CrossRef] [PubMed]

17. Xu, H.M.; Li, H.G.; Xu, L.-G.; Zhang, J.-R.; Chen, W.-Y.; Shi, Q.-X. The decline of fertility in male uremic patients is correlated with low expression of the cystic fibrosis transmembrane conductance regulator protein (CFTR) in human sperm. Hum. Reprod. 2011, 27, 340-348. [CrossRef]

18. Schaefer, F.; Van Kaick, B.; Veldhuis, J.D.; Stein, G.; Schärer, K.; Robertson, W.R.; Ritz, E. Changes in the kinetics and biopotency of luteinizing hormone in hemodialyzed men during treatment with recombinant human erythropoietin. J. Am. Soc. Nephrol. 1994, 5, 1208-1215. [PubMed]

19. Schaefer, R.M.; Kokot, F.; Wernze, H.; Geiger, H.; Heidland, A. Improved sexual function in hemodialysis patients on recombinant erythropoietin: A possible role for prolactin. Clin. Nephrol. 1989, 31, 1-5.

20. Bellinghieri, G.; Santoro, D.; Lo Forti, B.; Mallamace, A.; De Santo, R.M.; Savica, V. Erectile dysfunction in uremic dialysis pa-tients: Diagnostic evaluation in the sildenafil era. Am. J. Kidney Dis. 2001, 38 (Suppl. 1), S115-S117. [CrossRef]

21. Wiles, K.S.; Nelson-Piercy, C.; Bramham, K. Reproductive health and pregnancy in women with chronic kidney disease. Nat. Rev. Nephrol. 2018, 14, 165-184. [CrossRef] [PubMed]

22. Ahmed, S.B.; Ramesh, S. Sex hormones in women with kidney disease. Nephrol. Dial. Transplant. 2016, 31, 1787-1795. [CrossRef] [PubMed]

23. Cochrane, R.; Regan, L. Undetected gynaecological disorders in women with renal disease. Hum. Reprod. 1997, 12, 667-670. [CrossRef] [PubMed]

24. Piccoli, G.B.; Cabiddu, G.; Daidone, G.; Guzzo, G.; Maxia, S.; Ciniglio, I.; Postorino, V.; Loi, V.; Ghiotto, S.; Nichelatti, M.; et al. The children of dialysis: Live-born babies from on-dialysis mothers in Italy-an epidemiological perspective comparing dialysis, kidney transplantation and the overall population. Nephrol. Dial. Transplant. 2014, 29, 1578-1586. [CrossRef] [PubMed]

25. Knight, M.; Kurinczuk, J.J.; Tuffnell, D.; Brocklehurst, P. The UK Obstetric Surveillance System for rare disorders of pregnancy. BJOG 2005, 112, 263-265. [CrossRef]

26. Statistical Bulletin: Conceptions in England and Wales 2015. Office for National Statistics. 2017. Available online: https:/ /www.ons.gov. uk/peoplepopulationandcommunity/birthsdeathsandmarriages/conceptionandfertilityrates/bulletins/conceptionstatistics/2015 (accessed on 20 August 2018).

27. Ahmed, S.B.; Vitek, W.S.; Holley, J.L. Fertility, Contraception, and Novel Reproductive Technologies in Chronic Kidney Dis-ease. Semin. Nephrol. 2017, 37, 327-336. [CrossRef]

28. Matuszkiewicz-Rowinska, J.; Skórzewska, K.; Radowicki, S.; Niemczyk, S.; Sokalski, A.; Przedlacki, J.; Puka, J.; Switalski, M.; Wardyn, K.; Grochowski, J.; et al. Endometrial morphology and pituitary-gonadal axis dysfunction in women of reproduc-tive age undergoing chronic haemodialysis-A multicentre study. Nephrol. Dial. Transplant. 2004, 19, 2074-2077. [CrossRef]

29. Harlow, S.D.; Gass, M.; Hall, J.E.; Lobo, R.; Maki, P.; Rebar, R.W.; Sherman, S.; Sluss, P.M.; de Villiers, T.J.; STRAW+ 10 Collaborative Group. Executive summary of the Stages of Reproductive Aging Workshop + 10: Addressing the unfinished agenda of staging re-productive aging. J. Clin. Endocrinol. Metab. 2012, 97, 1159-1168. [CrossRef]

30. Rose, C.; Gill, J.; Zalunardo, N.; Johnston, O.; Mehrotra, A.; Gill, J.S. Timing of Pregnancy After Kidney Transplantation and Risk of Allograft Failure. Am. J. Transplant. 2016, 16, 2360-2367. [CrossRef]

31. Filocamo, M.T.; Zanazzi, M.; Marzi, V.L.; Lombardi, G.; Del Popolo, G.; Mancini, G.; Salvadori, M.; Nicita, G. Sexual Dysfunction in Women During Dialysis and after Renal Transplantation. J. Sex. Med. 2009, 6, 3125-3131. [CrossRef]

32. Barua, M.; Hladunewich, M.; Keunen, J.; Pierratos, A.; McFarlane, P.; Sood, M.; Chan, C.T. Successful Pregnancies on Nocturnal Home Hemodialysis. Clin. J. Am. Soc. Nephrol. 2008, 3, 392-396. [CrossRef] [PubMed]

33. Stoumpos, S.; Lees, J.; Welsh, P.; Hund, M.; Geddes, C.C.; Nelson, S.M.; Mark, P.B. The utility of anti-Müllerian hormone in women with chronic kidney disease, on haemodialysis and after kidney transplantation. Reprod. Biomed. Online 2018, 36, 219-226. [CrossRef] [PubMed]

34. Holley, J.L.; Schmidt, R.J. Sexual dysfunction in CKD. Am. J. Kidney Dis. 2010, 56, 612-614. [CrossRef]

35. Oliverio, A.L.; Bragg-Gresham, J.L.; Admon, L.K.; Nunes, J.A.W.; Saran, R.; Heung, M. Obstetric Deliveries in US Women With ESKD: 2002-2015. Am. J. Kidney Dis. 2020, 75, 762-771. [CrossRef] [PubMed]

36. Shahir, A.K.; Briggs, N.; Katsoulis, J.; Levidiotis, V. An observational outcomes study from 1966-2008, examining pregnancy and neonatal outcomes from dialysed women using data from the ANZDATA Registry. Nephrology 2013, 18, 276-284. [CrossRef] [PubMed]

37. Tong, A.; Jesudason, S.; Craig, J.C.; Winkelmayer, W.C. Perspectives on pregnancy in women with chronic kidney disease: Sys-tematic review of qualitative studies. Nephrol. Dial. Transplant. 2015, 30, 652-661. [CrossRef] [PubMed] 
38. Leroy, C.; Rigot, J.M.; Leroy, M.; Decanter, C.; Le Mapihan, K.; Parent, A.S.; Le Guillou, A.C.; Yakoub-Agha, I.; Dharancy, S.; Noel, C.; et al. Immunosuppressive drugs and fertility. Orphanet J. Rare Dis. 2015, 10, 136-151. [CrossRef]

39. Somers, E.C.; Marder, W.; Christman, G.M.; Ognenovski, V.; McCune, W.J. Use of a gonadotropin-releasing hormone analog for protection against premature ovarian failure during cyclophosphamide therapy in women with severe lupus. Arthritis Rheum. 2005, 52, 2761-2767. [CrossRef]

40. Lambertini, M.; Boni, L.; Michelotti, A.; Gamucci, T.; Scotto, T.; Gori, S.; Giordano, M.; Garrone, O.; Levaggi, A.; Poggio, F.; et al. Ovarian Suppression With Triptorelin During Adjuvant Breast Cancer Chemotherapy and Long-term Ovarian Function, Pregnancies, and Disease-Free Survival: A Randomized Clinical Trial. JAMA 2015, 314, 2632-2640. [CrossRef]

41. Hladunewich, M.; Schatell, D. Intensive dialysis and pregnancy. Hemodial. Int. 2016, 20, 339-348. [CrossRef] [PubMed]

42. Van Eps, C.; Hawley, C.; Jeffries, J.; Johnson, D.W.; Campbell, S.; Isbel, N.; Mudge, D.W.; Prins, J. Changes in serum prolactin, sex hormones and thyroid function with alternate nightly nocturnal home haemodialysis. Nephrology 2012, 17, 42-47. [CrossRef]

43. Piccoli, G.B.; Minelli, F.; Versino, E.; Cabiddu, G.; Attini, R.; Vigotti, F.N.; Rolfo, A.; Giuffrida, D.; Colombi, N.; Pani, A.; et al. Pregnancy in dialysis patients in the new millennium: A systematic review and meta-regression analysis correlating dialysis schedules and pregnancy outcomes. Nephrol. Dial. Transplant. 2016, 31, 1915-1934. [CrossRef]

44. Wiles, K.; Chappell, L.; Clark, K.; Elman, L.; Hall, M.; Lightstone, L.; Mohamed, G.; Mukherjee, D.; Nelson-Piercy, C.; Webster, P.; et al. Clinical practice guideline on pregnancy and renal disease. BMC Nephrol. 2019, 20, 401. [CrossRef]

45. Pietrzak, B.; Wielgos, M.; Kaminski, P.; Jabiry-Zieniewicz, Z.; Bobrowska, K. Menstrual cycle and sex hormone profile in kid-ney-transplanted women. Neuro Endocrinol. Lett. 2006, 27, 198-202.

46. Chakhtoura, Z.; Meunier, M.; Caby, J.; Mercadal, L.; Arzouk, N.; Barrou, B.; Touraine, P. Gynecologic follow up of 129 women on dialysis and after kidney transplantation: A retrospective cohort study. Eur. J. Obstet. Gynecol. Reprod. Biol. 2015, 187, 1-5. [CrossRef]

47. Akbari, F.; Alavi, M.; Esteghamati, A.; Mehrsai, A.; Djaladat, H.; Zohrevand, R.; Pourmand, G. Effect of renal transplantation on sperm quality and sex hormone levels. BJU Int. 2003, 92, 281-283. [CrossRef]

48. Tainio, J.; Jahnukainen, K.; Nurmio, M.; Pakarinen, M.; Jalanko, H.; Jahnukainen, T. Testicular function, semen quality, and fertili-ty in young men after renal transplantation during childhood or adolescence. Transplantation 2014, 98, 987-993. [CrossRef] [PubMed]

49. Eckersten, D.; Giwercman, A.; Pihlsgård, M.; Bruun, L.; Christensson, A. Impact of Kidney Transplantation on Reproductive Hormone Levels in Males: A Longitudinal Study. Nephron 2017, 138, 192-201. [CrossRef] [PubMed]

50. Prem, A.R.; Punekar, S.V.; Kalpana, M.; Kelkar, A.R.; Acharya, V.N. Male reproductive function in uraemia: Efficacy of haemodialysis and renal transplantation. Br. J. Urol. 1996, 78, 635-638. [CrossRef] [PubMed]

51. Rodrigues Netto, N., Jr.; Pecoraro, G.; Sabbaga, E.; Menezes de Góes, G. Spermatogenesis before and after renal transplant. Int. J. Fertil. 1980, 25, 131-133. [PubMed]

52. Eid, M.M.; Sobh, M.A.; Abdel-Hamid, I.A.; El-Saied, M.A. Assessment of sperm motion characteristics in infertile renal transplant recipients using computerized analysis. Int. J. Androl. 1996, 19, 338-344. [CrossRef]

53. Diemont, W.L.; Vruggink, P.A.; Meuleman, E.J.; Doesburg, W.H.; Lemmens, W.A.; Berden, J.H. Sexual dysfunction after renal re-placement therapy. Am. J. Kidney Dis. 2000, 35, 845-851. [CrossRef]

54. Stehman-Breen, C.O.; Gillen, D.; Gipson, D. Prescription of hormone replacement therapy in postmenopausal women with renal failure. Kidney Int. 1999, 56, 2243-2247. [CrossRef] [PubMed]

55. Lawrence, I.G.; Price, D.E.; Howlett, T.A.; Harris, K.P.; Feehally, J.; Walls, J. Correcting impotence in the male dialysis patient: Expe-rience with testosterone replacement and vacuum tumescence therapy. Am. J. Kidney Dis. 1998, 31, 313-319. [CrossRef] [PubMed]

56. Murray, J.E.; Reid, D.E.; Harrison, J.H.; Merrill, J.P. Successful Pregnancies after Human Renal Transplantation. N. Engl. J. Med. 1963, 269, 341-343. [CrossRef] [PubMed]

57. Deshpande, N.A.; James, N.T.; Kucirka, L.M.; Boyarsky, B.J.; Garonzik-Wang, J.M.; Montgomery, R.A.; Segev, D.L. Pregnancy out-comes in kidney transplant recipients: A systematic review and meta-analysis. Am. J. Transplant. 2011, 11, 2388-2404. [CrossRef]

58. Gill, J.S.; Zalunardo, N.; Rose, C.; Tonelli, M. The Pregnancy Rate and Live Birth Rate in Kidney Transplant Recipients. Arab. Archaeol. Epigr. 2009, 9, 1541-1549. [CrossRef]

59. Transplant Pregnancy Registry International (TPR). Annual Report 2017; Gift of Life Institute: Philadelphia, PA, USA, 2018.

60. Van Buren, M.C.; Schellekens, A.; Groenhof, T.K.J.; van Reekum, F.; van de Wetering, J.; Paauw, N.D.; Lely, A.T. Long-term Graft Sur-vival and Graft Function Following Pregnancy in Kidney Transplant Recipients: A Systematic Review and Meta-analysis. Transplantation 2020, 104, 1675-1685. [CrossRef]

61. Sibanda, N.; Briggs, J.D.; Davison, J.M.; Johnson, R.J.; Rudge, C.J. Pregnancy after Organ Transplantation: A Report from the U.K. Transplant Pregnancy Registry. Transplantation 2007, 83, 1301-1307. [CrossRef]

62. Díaz, J.M.; Canal, C.; Giménez, I.; Guirado, L.; Facundo, C.; Solà, R.; Ballarín, J. Pregnancy in recipients of kidney transplantation: Effects on mother and child. Nefrología 2008, 28, 174-177.

63. Rao, S.; Ghanta, M.; Moritz, M.J.; Constantinescu, S. Long-Term Functional Recovery, Quality of Life, and Pregnancy After Solid Organ Transplantation. Med. Clin. N. Am. 2016, 100, 613-629. [CrossRef] 
64. Mastrosimone, S.; Pignata, G.; Maresca, M.C.; Calconi, G.; Rabassini, A.; Butini, R.; Fandella, A.; Di Falco, G.; Chiara, G.; Caldato, C. Clinical significance of vesicoureteral reflux after kidney transplantation. Clin. Nephrol. 1993, 40, $38-45$.

65. Ajaimy, M.; Lubetzky, M.; Jones, T.; Kamal, L.; Colovai, A.; De Boccardo, G.; Akalin, E. Pregnancy in sensitized kidney transplant recipients: A single center experience. Clin. Transplant. 2016, 30, 791-795. [CrossRef]

66. Richman, K.; Gohh, R.; Peters, H.P.; Rumjon, A.; Bansal, S.S.; Laarakkers, C.M.; Brand, J.A.V.D.; Sarafidis, P.; Musto, R.; Malyszko, J.; et al. Pregnancy after renal transplantation: A review of registry and single-center practices and outcomes. Nephrol. Dial. Transplant. 2012, 27, 3428-3434. [CrossRef]

67. Deshpande, N.A.; James, N.T.; Kucirka, L.M.; Boyarsky, B.J.; Garonzik-Wang, J.M.; Cameron, A.M.; Singer, A.L.; Dagher, N.N.; Segev, D.L. Pregnancy outcomes of liver transplant recipients: A systematic review and meta-analysis. Liver Transplant. 2012, 18, 621-629. [CrossRef] [PubMed]

68. Moritz, M.J.; Constantinescu, S.; Coscia, L.A.; Armenti, D.; Transplant Pregnancy Registry International (TPR). Annual Report 2016; Gift of Life Institute: Philadelphia, PA, USA, 2017; pp. 1-23.

69. Coscia, L.A.; Constantinescu, S.; Moritz, M.J.; Frank, A.M.; Ramirez, C.B.; Doria, C.; McGrory, C.H.; Armenti, V.T. Report from the National Transplantation Pregnancy Registry (NTPR): Outcomes of pregnancy after transplantation. Clin. Transpl. 2008, 89-105, Chapter 8.

70. A Magee, L.; Von Dadelszen, P.; Darley, J.; Beguin, Y. Erythropoiesis and renal transplant pregnancy. Clin. Transplant. 2000, 14, 127-135. [CrossRef]

71. Sarkar, M.; Bramham, K.; Moritz, M.J.; Coscia, L. Reproductive health in women following abdominal organ transplant. Arab. Archaeol. Epigr. 2018, 18, 1068-1076. [CrossRef] [PubMed]

72. Westbrook, R.H.; Yeoman, A.D.; Agarwal, K.; Aluvihare, V.; O'Grady, J.; Heaton, N.; Penna, L.; Heneghan, M.A. Outcomes of pregnancy following liver transplantation: The King's College Hospital experience. Liver Transpl. 2015, 21, 1153-1159. [CrossRef] [PubMed]

73. Yildirim, Y.; Uslu, A. Pregnancy in patients with previous successful renal transplantation. Int. J. Gynecol. Obstet. 2005, 90, 198-202. [CrossRef] [PubMed]

74. Rafie, S.; Lai, S.; Garcia, J.E.; Mody, S.K. Contraceptive Use in Female Recipients of a Solid-Organ Transplant. Prog. Transplant. 2014, 24, 344-348. [CrossRef] [PubMed]

75. Xu, L.; Yang, Y.; Shi, J.G.; Wang, H.; Qiu, F.; Peng, W.; Fu, J.; Zhu, X.; Zhu, Y. Unwanted pregnancy among Chinese renal transplant recipients. Eur. J. Contracept. Reprod. Health Care 2011, 16, 270-276. [CrossRef] [PubMed]

76. Bramham, K.; Nelson-Piercy, C.; Gao, H.; Pierce, M.; Bush, N.; Spark, P.; Brocklehurst, P.; Kurinczuk, J.J.; Knight, M. Pregnancy in Renal Transplant Recipients: A UK National Cohort Study. Clin. J. Am. Soc. Nephrol. 2012, 8, 290-298. [CrossRef] [PubMed]

77. Kasiske, B.L.; Zeier, M.G.; Chapman, J.R.; Craig, J.C.; Ekberg, H.; Garvey, C.A.; Green, M.D.; Jha, V.; Josephson, M.A.; Kiberd, B.A.; et al. KDIGO clinical practice guideline for the care of kidney transplant recipients: A summary. Kidney Int. 2010, 77, $299-311$. [CrossRef] [PubMed]

78. Piccoli, G.B.; Cabiddu, G.; Attini, R.; Vigotti, F.N.; Maxia, S.; Lepori, N.; Tuveri, M.; Massidda, M.; Marchi, C.; Mura, S.; et al. Risk of Adverse Pregnancy Outcomes in Women with CKD. J. Am. Soc. Nephrol. 2015, 26, 2011-2022. [CrossRef]

79. You, J.Y.; Kim, M.-K.; Choi, S.-J.; Oh, S.-Y.; Kim, S.-J.; Kim, J.-H.; Oh, H.-Y.; Roh, C.-R. Predictive factors for adverse pregnancy outcomes after renal transplantation. Clin. Transplant. 2014, 28, 699-706. [CrossRef]

80. Davison, J.M.; Lindheimer, M.D. Pregnancy and Chronic Kidney Disease. Semin. Nephrol. 2011, 31, 86-99. [CrossRef]

81. Piccoli, G.B.; Cabiddu, G.; Attini, R.; Gerbino, M.; Todeschini, P.; Perrino, M.L.; Manzione, A.M.; Piredda, G.B.; Gnappi, E.; Caputo, F.; et al. Outcomes of Pregnancies After Kidney Transplantation: Lessons Learned From CKD. A Comparison of Transplanted, Nontransplanted Chronic Kidney Disease Patients and Low-Risk Pregnancies: A Multicenter Nationwide Analysis. Transplantation 2017, 101, 2536-2544. [CrossRef]

82. McKay, D.B.; Josephson, M.A.; Armenti, V.T.; August, P.; Coscia, L.A.; Davis, C.L.; Davison, J.M.; Easterling, T.; Friedman, J.E.; Hou, S.; et al. Reproduction and transplantation: Report on the AST Consensus Conference on Reproductive Issues and Transplantation. Am. J. Transplant. 2005, 5, 1592-1599. [CrossRef] [PubMed]

83. Cabiddu, G.; Spotti, D.; Gernone, G.; Santoro, D.; Moroni, G.; Gregorini, G.; Giacchino, F.; Attini, R.; Limardo, M.; Gammaro, L.; et al. A best-practice position statement on pregnancy after kidney transplantation: Focusing on the unsolved questions. The Kidney and Pregnancy Study Group of the Italian Society of Nephrology. J. Nephrol. 2018, 31, 665-681. [CrossRef] [PubMed]

84. McKay, D.B.; Josephson, M.A. Pregnancy in Recipients of Solid Organs-Effects on Mother and Child. N. Engl. J. Med. 2006, 354, 1281-1293. [CrossRef]

85. Levitz, M.; Jansen, V.; Dancis, J. The transfer and metabolism of corticosteroids in the perfused human placenta. Am. J. Obstet. Gynecol. 1978, 132, 363-366. [CrossRef]

86. Carmichael, S.L.; Shaw, G.M.; Ma, C.; Werler, M.M.; Rasmussen, S.A.; Lammer, E.J. National Birth Defects Prevention Study. Maternal corticosteroid use and orofacial clefts. Am. J. Obstet. Gynecol. 2007, 197, 585.e1-585.e7. [CrossRef]

87. Hebert, M.F.; Zheng, S.; Hays, K.; Shen, D.D.; Davis, C.L.; Umans, J.G.; Miodovnik, M.; Thummel, K.E.; Easterling, T.R. Interpreting Tacrolimus Concentrations During Pregnancy and Postpartum. Transplantation 2013, 95, 908-915. [CrossRef]

88. Mason, R.J.; Thomson, A.W.; Whiting, P.H.; Gray, E.S.; A Brown, P.; Catto, G.R.; Simpson, J.G. Cyclosporine-induced fetotoxicity in the rat. Transplantation 1985, 39, 9-12. 
89. Paziana, K.; Del Monaco, M.; Cardonick, E.; Moritz, M.; Keller, M.; Smith, B.; Coscia, L.; Armenti, V. Ciclosporin Use During Pregnancy. Drug Saf. 2013, 36, 279-294. [CrossRef]

90. EBPG Expert Group on Renal Transplantation. European best practice guidelines for renal transplantation. Section IV: Long-term management of the transplant recipient. IV.10. Pregnancy in renal transplant recipients. Nephrol. Dial. Transplant. 2002, 17 (Suppl. 4), 50-55.

91. Hoeltzenbein, M.; Elefant, E.; Vial, T.; Finkel-Pekarsky, V.; Stephens, S.; Clementi, M.; Allignol, A.; Weber-Schoendorfer, C.; Schaefer, C. Teratogenicity of mycophenolate confirmed in a prospective study of the European Network of Teratology Information Services. Am. J. Med. Genet. Part A 2012, 158, 588-596. [CrossRef] [PubMed]

92. Moritz, M.J.; Constantinescu, S.; Coscia, L.A.; Armenti, D. Mycophenolate and Pregnancy: Teratology Principles and National Transplantation Pregnancy Registry Experience. Arab. Archaeol. Epigr. 2017, 17, 581-582. [CrossRef] [PubMed]

93. King, R.W.; Baca, M.J.; Armenti, V.T.; Kaplan, B. Pregnancy Outcomes Related to Mycophenolate Exposure in Female Kidney Transplant Recipients. Arab. Archaeol. Epigr. 2016, 17, 151-160. [CrossRef] [PubMed]

94. Constantinescu, S.; Coscia, L.A.; Armenti, V.T. Mycophenolic acid product discontinuation prior to conception: Analysis of pregnancies in kidney transplant recipients. Am. J. Transplant. 2016, 16, 228.

95. Braun, M.; Young, J.; Reiner, C.S.; Poster, D.; Krauer, F.; Kistler, A.D.; Kristanto, P.; Wang, X.; Liu, Y.; Loffing, J.; et al. Low-dose oral sirolimus and the risk of menstrual-cycle disturbances and ovarian cysts: Analysis of the randomized controlled SUISSE ADPKD trial. PLoS ONE 2012, 7, e45868. [CrossRef]

96. Carta, P.; Caroti, L.; Zanazzi, M. Pregnancy in a Kidney Transplant Patient Treated With Everolimus. Am. J. Kidney Dis. 2012, 60, 329. [CrossRef] [PubMed]

97. Pendergraft, W.F., 3rd; McGrath, M.M.; Murphy, A.P.; Murphy, P.; Laliberte, K.A.; Greene, M.F.; Niles, J.L. Fetal outcomes after rituxi-mab exposure in women with autoimmune vasculitis. Ann. Rheum. Dis. 2013, 72, 2051-2053. [CrossRef] [PubMed]

98. Xu, L.; Wang, H.; Peng, W.; Jin, L.; Zhu, X.; Xu, H.; Song, Q.; Xu, B.; Ding, X. Marital Status and Fertility of 185 Male Renal Transplant Recipients in China. J. Androl. 2008, 29, 618-621. [CrossRef] [PubMed]

99. Jones, A.; Clary, M.J.; McDermott, E.; Coscia, L.A.; Constantinescu, S.; Moritz, M.J.; Armenti, V.T. Outcomes of Pregnancies Fathered by Solid-Organ Transplant Recipients Exposed to Mycophenolic Acid Products. Prog. Transplant. 2013, 23 , $153-157$. [CrossRef]

100. Midtvedt, K.; Bergan, S.; Reisæter, A.V.; Vikse, B.E.; Åsberg, A. Exposure to Mycophenolate and Fatherhood. Transplantation 2017, 101, e214-e217. [CrossRef] [PubMed]

101. Tondolo, V.; Citterio, F.; Panocchia, N.; Nanni, G.; Castagneto, M. Sirolimus Impairs Improvement of the Gonadal Function after Renal Transplantation. Arab. Archaeol. Epigr. 2005, 5, 197. [CrossRef]

102. Liu, S.; Huang, L.; Geng, Y.; He, J.; Chen, X.; Xuemei, C.; Junlin, H.; Wang, Y.; Ding, Y.; Liu, X. Rapamycin inhibits spermatogenesis by changing the autophagy status through suppressing mechanistic target of rapamycin-p70S6 kinase in male rats. Mol. Med. Rep. 2017, 16, 4029-4037. [CrossRef]

103. Zuber, J.; Anglicheau, D.; Elie, C.; Bererhi, L.; Timsit, M.O.; Mamzer-Bruneel, M.F.; Ciroldi, M.; Martinez, F.; Snanoudj, R.; Hiesse, C.; et al. Sirolimus may reduce fertility in male renal transplant recipients. Am. J. Transplant. 2008, 8, 1471-1479. [CrossRef]

104. Lundy, S.D.; Vij, S.C. Male infertility in renal failure and transplantation. Transl. Androl. Urol. 2019, 8, 173-181. [CrossRef] [PubMed]

105. Blume, C.; Pischke, S.; Von Versen-Höynck, F.; Günter, H.; Gross, M. Pregnancies in liver and kidney transplant recipients: A review of the current literature and recommendation. Best Pract. Res. Clin. Obstet. Gynaecol. 2014, 28, 1123-1136. [CrossRef]

106. Piccoli, G.B.; Cabiddu, G.; Attini, R.; Gerbino, M.; Todeschini, P.; Perrino, M.L.; Manzione, A.M.; Piredda, G.B.; Gnappi, E.; Caputo, F.; et al. Pregnancy outcomes after kidney graft in Italy: Are the changes over time the result of different therapies or of different policies? A nationwide survey (1978-2013). Nephrol. Dial. Transplant. 2016, 31, 1957-1965. [CrossRef]

107. Parazzini, F.; Cortinovis, I.; Bortolus, R.; Soliani, A.; Fedele, L. Weight at birth of singleton live births between the 23rd and 27th week of gestation delivered vaginally or by cesarean section. Acta Paediatr. 1994, 83, 1206-1208. [CrossRef] [PubMed]

108. Shah, S.; Venkatesan, R.L.; Gupta, A.; Sanghavi, M.K.; Welge, J.; Johansen, R.; Kean, E.B.; Kaur, T.; Gupta, A.; Grant, T.J.; et al. Pregnancy outcomes in women with kidney transplant: Metaanalysis and systematic review. BMC Nephrol. 2019, 20, 24. [CrossRef]

109. Durst, J.K.; Rampersad, R.M. Pregnancy in Women with Solid-Organ Transplants: A Review. Obstet. Gynecol. Surv. 2015, 70, 408-418. [CrossRef]

110. Sturgiss, S.; Davison, J. Effect of pregnancy on the long-term function of renal allografts: An update. Am. J. Kidney Dis. 1995, 26, 54-56. [CrossRef]

111. Fischer, T.; Neumayer, H.-H.; Fischer, R.; Barenbrock, M.; Schobel, H.P.; Lattrell, B.C.; Jacobs, V.R.; Paepke, S.; Von Steinburg, S.P.; Schmalfeldt, B.; et al. Effect of Pregnancy on Long-Term Kidney Function in Renal Transplant Recipients Treated with Cyclosporine and with Azathioprine. Arab. Archaeol. Epigr. 2005, 5, 2732-2739. [CrossRef]

112. First, M.R.; A Combs, C.; Weiskittel, P.; Miodovnik, M. Lack of effect of pregnancy on renal allograft survival or function. Transplantation 1995, 59, 472-476. [CrossRef]

113. Candido, C.; Cristelli, M.P.; Fernandes, A.R.; De Lima, A.C.A.; Viana, L.A.; Sato, J.L.; Sass, N.; Tedesco-Silva, H.; Medina-Pestana, J.O. Pregnancy after kidney transplantation: High rates of maternal complications. Braz. J. Nephrol. 2016, 38, 421-426. [CrossRef] [PubMed] 
114. Keitel, E.; Bruno, R.; Duarte, M.; Santos, A.; Bittar, A.; Bianco, P.; Goldani, J.; Garcia, V. Pregnancy outcome after renal transplantation. Transplant. Proc. 2004, 36, 870-871. [CrossRef] [PubMed]

115. Kwek, J.L.; Tey, V.; Yang, L.; Kanagalingam, D.; Kee, T. Renal and obstetric outcomes in pregnancy after kidney transplantation: Twelve-year experience in a Singapore transplant center. J. Obstet. Gynaecol. Res. 2015, 41, 1337-1344. [CrossRef] [PubMed]

116. Levidiotis, V.; Chang, S.; McDonald, S. Pregnancy and Maternal Outcomes Among Kidney Transplant Recipients. J. Am. Soc. Nephrol. 2009, 20, 2433-2440. [CrossRef] [PubMed]

117. Rahamimov, R.; Ben-Haroush, A.; Wittenberg, C.; Mor, E.; Lustig, S.; Gafter, U.; Hod, M.; Bar, J. Pregnancy in renal transplant recipients: Long-term effect on patient and graft survival. A single-center experience. Transplantation 2006, 81, 660-664. [CrossRef] [PubMed] 